\title{
Pharmacological Evaluation of Tamarix aphylla for Anti-inflammatory, Anti-pyretic and Anti-nociceptive Activities in Standard Animal Models

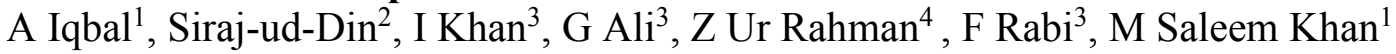

\begin{abstract}
Objectives: The objective of this study was to assess anti-inflammatory, anti-pyretic and antinociceptive activities of methanol extract of Tamarix Aphylla (TAME) in experimental animal models.
\end{abstract}

Methods: The TAME was evaluated via carrageenan induced edema and xylene induced ear edema models for anti-inflammatory, brewer yeast induced pyrexia model for anti-pyretic activity, hot plate and acetic acid induced writhing models for anti-nociceptive properties.

Results: The outcomes indicated that TAME in inflammatory models at a dose level of 100 and $200 \mathrm{mg} / \mathrm{kg}$ exhibited statistically significant anti-inflammatory activity $51.84 \%$ / $68.59 \%$ and $36.00 \% / 61.17 \%$ respectively. Similarly, TAME exhibited the maximum antipyretic effect at a dose level of 100 and $200 \mathrm{mg} / \mathrm{kg}$, which was $2.08 \%$ and $2.72 \%$ respectively. Moreover, the TAME demonstrated maximum percent inhibitory activity with a dose of $400 \mathrm{mg} / \mathrm{kg}$ in writhing and hot plate tests which was $50.40 \%$ and $46.56 \%$ respectively.

Conclusion: In conclusion, this study provides a pharmacological basis for the ethnopharmacological use of Tamarix aphylla as anti-inflammatory, anti-pyretic and analgesic herbal remedy.

Keywords: Analgesic, anti-inflammatory, antipyretic, Tamarix aphylla

Affiliations: ${ }^{1}$ Department of Botany, Islamia College Peshawar 25120, KP, Pakistan, ${ }^{2}$ Department of Botany, University of Peshawar 25120, KP, Pakistan, ${ }^{3}$ Department of Pharmacy, University of Peshawar25120, KP, Pakistan, ${ }^{4}$ Department of Environmental Sciences, University of Haripur, Pakistan.

Correspondence: Dr G Ali, Department of Pharmacy, University of Peshawar, Peshawar, Pakistan. Fax: +92-91921813, e-mail: gowhar_ali@upesh.edu.pk., gohar.pharmacist@gmail.com 


\section{INTRODUCTION}

Appropriate monitoring of inflammation, pyrexia and pain is a major confront for clinicians. Natural products with desirable pharmacological profile are greatly exigent in the health care community. In literature studies, different strategies have been reported for natural products based drug discovery including ethnopharmacology, reverse pharmacognosy, virtual screening of isolated compounds, random screening and bioactivity-guided isolation (1-3). This study was designed to randomly screen the plant methanol extract, against a set of standard animal models to identify their therapeutic potential.

Tamarix aphylla (L) (common name, athel pine) is an evergreen, perennial tree (Fig. 1). It belongs to tamaricaceae family. It is cultivated from seeds. It is a spreading tree of about 15 meters in height. It has pendulous jointed branches. The small needles like leaves which are dull green and similar to those found in pines. The leaves are sessile, alternately positioned, entire and minutely cuspidate. The flowers are stalkless, small in size, having pinkish-white color. The fruit of Tamarix aphylla is bell shaped with a hairy bunch. It has many small and cylindrical shaped seeds. The roots of this tree are strong and woody. They penetrate and spread deeply in the soil (4-8).

Tamarix aphylla is considered the most common species cultivated across the country, Pakistan (9). It has worldwide distribution. It is found across the globe in Africa (Sudan, Tunisia, Morocco, Algeria, Abyssinia, Kenya, Egypt, Libya, Somalia, Eritrea and Senegal), Middle East (Yemen, Jordan, Kuwait, Saudi Arabia, Iran, Israel, Iraq), Afghanistan, India and South West United States, from Texas to California $(6,8,9)$. Tamarix aphylla is commonly found on saline habitats like salt flats, springs, along the streams and rivers $(10,11)$. It has also 
been found along the Salton Sea Basin and Coloradoan Gila Rivers (12). Tamarix aphylla is also distributed with irrigation ditches in the bottomlands (13).

Tamarix aphylla leaves contains alkaloids, flavonoids, steroids, cardiac glycosides, terpenoides, tannins and saponins (14). The bark of Tamarix aphylla reported to possess bioactive agents such as triterpene D-friedoolean-14-en-3 $\alpha$, 3-ketone, $3 \beta$ isomer (myricadiol) and 28-diol (isomyricadiol) (15). From the stem bark of Tamarix aphylla many other active compounds have been isolated and characterized including diaryloxyfuranofuranlignan, isoferulylglyceryl ester, polyphenolic and dehydrodigallic acid etc (15).

Several ethnobotanical and pharmacological activities has been reported for Tamarix aphylla like antioxidant activity (14), use in jaundice, rheumatism, bad evils, wound and abscesses (16). The green leaves of Tamarix aphylla are consumed by camels as food (9). Therapeutic uses of Tamarix aphylla reveal that the gall and bark of the tree are used as astringent, tonic and aphourodisiac. It is also used in the management of syphilis, eczema, skin diseases, hepatitis and scaly skin disease (17). The leaves of the plant have been reported to have germicidal potential. It is also used in eye inflammation, fever, toothache (dental pain), wound healing, inflammation, cold and flu $(18,19)$. The extracts from the leaves are applied in treatment of tetanus (16). The bark (ground part) is applied on wounds for healing $(9,20,21)$. The present study is a part of our major study to screen local flora of Khyber-Pakhtunkhwa (KP) (22), Pakistan in order to validate scientifically the ethnopharmacological uses of Tamarix aphylla. 


\section{MATERIALS AND METHODS}

\section{Chemicals and instruments}

Yeast brewer (Merck, Germany), lambda Carrageenan (Sigma, USA), glacial acetic acid (Panreac, Spain), digital plethysmometer (Model LE 7500 Plan lab S.L.), hot plate analgesiometer (Harvard apparatus, USA), digital thermometer (Model CA92121, ACON Laboratories, USA). All other chemicals purchased were of analytical grades.

\section{Collection of plant materials}

Tamarix aphylla was collected from Pakistan Forest Institute, University of Peshawar. The plant was identified by Professor Dr. Siraj-ud-Din, chairman, department of botany, university of Peshawar, given voucher number AI001ICP and placed in herbarium, Department of Botany, Islamia College Peshawar, KP, Pakistan.

\section{Extraction of plant materials}

The collected plant part, i.e. stem bark was shade dried for three weeks at room temperature. The dried stem barks of plant were processed with an electric grinder for powder formation. $600 \mathrm{gm}$ powder of each plant was soaked in commercial grade methanol $(6.3,4.3,5$ and $4.35 \mathrm{~L}$, respectively) for 15 days at room temperature with occasional shaking. After 15 days, it was filtered and the methanol soluble residue obtained was concentrated with a rotary evaporator at $40^{\circ} \mathrm{C}$.

\section{Experimental animals}

During pharmacological experiments, albino BALB/C laboratory mice of either sex were used throughout the study period. To keep these animals healthy, recommended guidelines were followed throughout the experiments (23). The present research work was approved by departmental ethical committee and experiments were carried out in PCSIR-Complex, Peshawar. 
A total of six animals (mice) per group for each test dose in each experiment were used. Different experimental protocols (animal models) have been reported to study analgesic, antipyretic and anti-inflammatory activities such as chemically induced nociceptive models (bradykinin intra-arterial model, writhing model, formalin model, randall-sellitto model), thermally induced models (hot plate model, tail immersion model, radiant heat model), mechanically stimulated models (hafner's tail clip model) and electrically stimulated models (tooth pulp stimulation model, tail stimulation electrical model, flinch- jump model). We have selected specific standard animal models which have huge reported citations in the literature.

\section{Anti-inflammatory activity}

The methanol extract was subjected for evaluating anti-inflammatory activity by two standard animal models i.e. Carrageenan induced edema and xylene induced ear edema models.

\section{Carrageenan Induced Paw Edema Model:}

Tested animals (mice) of either sex (25-30 g body weights) were chosen for this purpose. The animals were distributed into five different groups. In every group, there were six animals $(\mathrm{n}=$ 6). Two groups (I \& II) were selected as negative and positive control respectively. Group I was administered with normal saline by the dose of $10 \mathrm{ml} \mathrm{kg}^{-1}$ (body weight). Indomethacin (standard drug) was administered at a dose of $10 \mathrm{mg} / \mathrm{kg}$ (body weight) to group II $(24,25)$. Remaining groups III, IV \& V were subjected with extract at a doses of 50, 100 and $200 \mathrm{mg} / \mathrm{kg}$ (body weight). Carrageenan of $1 \%$ was injected in sub-planter tissue of the hind paw (right) of every animal (mouse), 30 minutes after above mentioned treatments. Anti-inflammatory potential was recorded for 5 hours $(0,1,2,3,4$ and 5 hours by using plethysmometer (LE 7500 plan lab S.L) after the administration of carrageenan (26). The \% inhibition of edema was measured with the help of formula given below. 
$\%$ Inhibition $=\mathrm{A}-\mathrm{B} / \mathrm{B} \times 100$

In which;

$\mathrm{A}=$ edema volume in negative control

$\mathrm{B}=$ paw edema in tested groups.

\section{Xylene-Induced Ear Edema}

All the tested animals were distributed in five groups (six mice in each group) and administered with saline $(10 \mathrm{ml} / \mathrm{kg})$, plant extracts $(50-200 \mathrm{mg} / \mathrm{kg})$ and dexamethasone $(1 \mathrm{mg} / \mathrm{kg})$ in xylene induced ear edema study. After $30 \mathrm{~min}$, xylene $(0.03 \mathrm{ml})$ was applied to the inner surface of the right ear for the induction of edema. The left ear was used as control. Then after $15 \mathrm{~min}$, killed the mice with the help of ether anesthesia. Cut off both ears and then weighed. For each group, the mean of the difference between the left \& right ears was calculated (27). The percent inhibitory effect was measured with the help of formula given below.

$\%$ inhibition $=100(\mathrm{Vc}-\mathrm{Vt} / \mathrm{Vc})$

In which;

$\mathrm{Vc}=$ difference in weight of ear in control

$\mathrm{Vt}=$ difference in weight of ear in group treated with standard \& extract.

\section{Antipyretic activity}

\section{Pyrexia induction with Brewer's Yeast}

The antipyretic effect of methanol extract was screened in mice (30-35 g) of either sex. Before screening, mice were provided with water only for 12 hours. The tested animals were separated into five different groups $(\mathrm{n}=6)$. The group I was negative and group II was treated as positive control. The animals of group I were administered with normal saline at a dose of $10 \mathrm{ml} / \mathrm{kg}$ 
(body weight). Group II was treated with paracetamol at $150 \mathrm{mg} / \mathrm{kg}$ dose (body weight). Groups III, IV \& V were subjected with extract at doses of $100,200 \& 300 \mathrm{mg} / \mathrm{kg}$ (body weight). Normal body temperature of every animal was recorded with the help of the digital thermometer. To induce pyrexia, an aqueous suspension of Brewer's (15\%) was subcutaneously injected with a dose of $10 \mathrm{ml} / \mathrm{kg}$ in mice. After 24 hours, rise in body temperature was noted using digital thermometer. Those mice were selected for further study that showed at least $0.5{ }^{\circ} \mathrm{C}$ increase in body temperature while those animals were excluded who showed rise in body temperature less than $0.5{ }^{\circ} \mathrm{C}$ (28). Thorough intraperitoneal route all doses of extracts were injected. The temperature of rectum was noted regularly at 1 st, 2 nd, 3 rd, 4 th $\& 5$ th hour of each mouse in all treated groups. Reduction in body temperature (\%) was measured by the formula given below: $\%$ Reduction in body temperature $=100-\mathrm{B}-\mathrm{Cn} / \mathrm{B}-\mathrm{A} \times 100$ In which;

A =Normal body temperature;

$\mathrm{B}=$ Body temperature after 24 hours

$\mathrm{C}=$ Temperature at 1st, 2nd, 3rd, 4th and 5th hour of treatment.

\section{Antinociceptive activity}

Following protocols were used to ascertain analgesic potential of the plant methanol extract. Acetic Acid Induced Writhing Test

The tested animals (mice) of either sex in weight range of 18-22 g were selected in this experiment. The mice were divided into five different groups $(\mathrm{n}=6)$. Among these groups, group I, was negative control while group II, was treated as positive control. The normal saline at a dose of $10 \mathrm{ml} / \mathrm{kg}$ (body weight) was administered to group I (negative control), while group II was subjected with diclofenac sodium (standard drug) at the dose of $10 \mathrm{mg} / \mathrm{kg}$ (body weight). 
They were fed according to the recommended guidelines. Two hours before the start of activity, the food supply was stopped (23). Groups III, IV \& V (remaining groups) were subjected with extract at 100, $200 \& 400 \mathrm{mg} / \mathrm{kg}$ doses (body weight) respectively.

After administration of extract, waited for 30 minutes. After this, acetic acid (1\%) was injected to all tested groups thorough intra-peritoneal route. The abdominal writhing (constrictions) were started five minutes after acetic acid injection, which were counted for next 10 minutes. The analgesic potential (percent) was calculated with the help of the following given formula:

$\%$ analgesic effect $=100$-No of writhes in tested animals/No of writhes in control animals $\times 100$

\section{Antinociceptive effect by hot plate method}

In this experiment, analgesic effect was measured by using Hot Plate method (29). For this purpose, hot plate was maintained at a temperature of $55 \pm 1^{0} \mathrm{C}$ and tested animals (mice) were placed on hot plate individually. Every mouse was observed for reaction on hot plate in the form of licking or jumping. The animals used in this experiment were randomly selected. These selected mice were separated into five groups, I-V. Each group consisted of six mice for both control and test samples. All of the above mentioned groups were given a particular treatment, i.e. positive control with Tramadol in $20 \mathrm{mg} / \mathrm{kg}$, p.o and the test samples (plants extract) of 200 and $400 \mathrm{mg} / \mathrm{kg}$ respectively.

The animals were placed on hot plate maintained at a temperature of $55 \pm 1^{0} \mathrm{C}$. The time of 15 seconds was a cut off period to observe animals on a hot plate. After the treatment, the reaction time in treated and control animals was recorded at $0,30,60,90$ and 120 minutes (30). Statistical analysis 
Statistical package of graph pad prism, version 5 was used for analysis. ANOVA followed by appropriate post-hoc analysis was applied to data for statistical significance. Values of $p<0.05$ were considered significant in all cases.

\section{RESULTS}

\section{Anti-Inflammatory Activity}

Anti-Inflammatory Activity

Effect of the methanol extract of Tamarix aphylla (TAME) in carrageenan induced paw edema model

Anti-inflammatory effect of the methanol extract of Tamarix Aphylla (TAME) in carrageenan induced paw edema model has been shown in Table I. Statistical analysis of the data indicated that the anti-inflammatory activity of the tested plant was time and dose dependent. After 5 hours, maximum anti-inflammatory activity of $51.84 \%$ was observed with a dose of $200 \mathrm{mg} / \mathrm{kg}$, followed by $100 \mathrm{mg} / \mathrm{kg}$ that showed $36.00 \%$ inhibition. At the dose of $50 \mathrm{mg} / \mathrm{kg}$, the inhibitory activity was $30.84 \%$ after 5 hours. Similarly, at 3 hours, maximum inhibition was shown by 200 $\mathrm{mg} / \mathrm{kg}$, which was $42.23 \%$, followed by $100 \mathrm{mg} / \mathrm{kg}(23.82 \%)$.

Effect of the methanol extract of Tamarix Aphylla (TAME) in xylene-induced ear edema model Anti-inflammatory effect of the methanol extract of Tamarix Aphylla (TAME) in xylene induced ear edema model has been shown in Table II. Statistical analysis of the data revealed that the inhibitory effect in the cite model, was time and dose dependent. With the increasing dose of the plant extract, the inhibitory effect was also increased. The tested plant showed antiinflammatory activity significantly at all subjected doses, but more significant at 100 and 200 
$\mathrm{mg} / \mathrm{kg}$. Maximum anti-inflammatory activity of $68.59 \%$ was demonstrated by dose of 200 $\mathrm{mg} / \mathrm{kg}$ after 60 minutes. The effect for the same dose was $62.53 \%$, after 15 minutes. The dose of $100 \mathrm{mg} / \mathrm{kg}$ also demonstrated more significant anti-inflammatory effect at 60 minutes which was $61.17 \%$. It was $53.84 \%$ after 15 minutes for the same dose. Similarly, inhibitory activity measured for $50 \mathrm{mg} / \mathrm{kg}$ was $53.16 \%$ and $39.56 \%$ at 60 and 15 minutes respectively. Antipyretic Activity

Effect of the methanol extract of Tamarix Aphylla (TAME) in Brewer Yeast Induced Pyrexia Model

The antipyretic effect of the methanol extract of Tamarix Aphylla (TAME) in Brewer yeast induced pyrexia model has been depicted in Table III. The tested plant showed a significant antipyretic effect at tested doses during the whole duration ( 1 to 5 hours) except the dose of 100 mg which did not show any significant result at first hour $(38.61 \pm 0.24)$. The antipyretic potential of all the subjected doses in the first hour was $38.61 \pm 0.24,38.47^{*} \pm 0.64$, $38.23^{*} \pm 0.56$ at 100,200 and $300 \mathrm{mg} / \mathrm{kg}$ respectively. The reduction in temperature in $2 \mathrm{nd}$ hour of the treatment, for 100,200 and $300 \mathrm{mg} / \mathrm{kg}$ was $38.44^{*} \pm 0.41,38.09^{*} \pm 0.43$ and $37.92 * * \pm 0.47$ respectively. The rectal temperature measured for applied test doses at $3^{\text {rd }}$ hour was $38.07^{*} \pm 0.71,37.81^{* *} \pm 0.49$ and $37.56^{* *} \pm 0.54$ respectively. The antipyretic activity of $38.11^{*} \pm 0.49,37.84 * * \pm 0.36$ and $37.69^{* *} \pm 0.51$ was demonstrated by 100,200 and $300 \mathrm{mg} / \mathrm{kg}$ doses respectively in 4 th hour of the treatment. At 5 th hour, the rectal temperature measured was $38.09^{*} \pm 0.37,37.84 * * \pm 0.47,37.58 * * \pm 0.38$ respectively for 100,200 and $300 \mathrm{mg} / \mathrm{kg}$. Antinociceptive activity Effect of the methanol extract of Tamarix Aphylla (TAME) in Acetic Acid Induced Writhing Test 
Table IV, indicates the analgesic activity of the methanol extract of Tamarix Aphylla (TAME) at various doses $(100,200$ and $400 \mathrm{mg} / \mathrm{kg})$. The inhibitory effect of the tested plant was dose dependent. The maximum percent inhibitory activity was demonstrated by $400 \mathrm{mg} / \mathrm{kg}$ which was $50.40 \%$ (This inhibition was more significant) followed by $200 \mathrm{mg} / \mathrm{kg}(37.26 \%)$. Similarly, the percent writing inhibitory effect measured for $100 \mathrm{mg} / \mathrm{kg}$ was $13.68 \%$.

Effect of the methanol extract of Tamarix Aphylla (TAME) in Hot Plate Test:

The results of antinociceptive response of hot plate model is depicted in Table V. The antinociceptive response, after 30 minutes of the administered doses (200 and $400 \mathrm{mg} / \mathrm{kg}$ ) of the methanol extract of Tamarix Aphylla (TAME) was $9.89 \pm 0.52$ and $11.71 \pm 0.64 *$ respectively. In 1hour of the treatment, the latency of nociceptive response of $200 \mathrm{mg} / \mathrm{kg}$ was significant $\left(11.71 \pm 0.67^{*}\right)$ but was more significant at $400 \mathrm{mg} / \mathrm{kg}\left(12.89 \pm 0.63^{* *}\right)$. Similarly, the analgesic activity measured for 200 and $400 \mathrm{mg} / \mathrm{kg}$ was significant and more significant respectively at 90 and 120 minutes. The effect at 90 minutes for the doses of 200 and $400 \mathrm{mg} / \mathrm{kg}$ was $11.94 \pm 0.41^{*}$, $13.41 \pm 0.47^{* *}$ respectively. At 2 hours, latency of nociceptive response exhibited by tested doses was found more significant at the dose of $400 \mathrm{mg} \mathrm{kg}^{-1}$ which was $12.81 \pm 0.47 * *(* * \mathrm{P}<0.01)$.

\section{DISCUSSION}

It is a well-documented fact that that sub-chouronic or chouronic use of nonsteroidal or steroidal anti-inflammatory drugs (NSAIDS/SAIDS) depicts multi adverse effects specifically gastrointestinal tract (GIT) related like peptic ulcer, perforation and hemorrhage $(31,32)$, while narcotic analgesics most commonly associated with drug addiction and dependence. Consequently, there is an overt desire for alternative medicine to traditional NSAIDs/SAIDS that 
have a desirable profile with respect to anti-inflammatory, anti-nociceptive and anti-pyretic activities still devoid of such adverse effects. Therefore, natural product research is in dynamic to explore new sources of natural analgesics. Certain chemical substances such as serotonin, histamines and some other related compounds released in the first phase (90-180 minutes) of inflammation while increase in the volume of hind paw characterized the second phase of inflammation (270-360 minutes). This increase in volume is due to presence of certain inflammatory mediators (33). The in-vivo anti-inflammatory activity of Tamarix aphylla extract, revealed that the carrageenan produced biphasic inflammatory events had been controlled significantly $(p<0.05)$ by plant extract and hence might be useful as active anti-inflammatory agents.

The tested plant extract exerted a significant $(* * \mathrm{P}<0.01)$ inhibition at highest dose $(200$ $\mathrm{mg} / \mathrm{kg}$ ), which might be due to prostaglandin inhibition or phospholipase $\mathrm{A}_{2}$ inhibition. This phospholipase $\mathrm{A}_{2}$ has a key role in xylene induced inflammation (34). The selected plant has been found effective at the subjected doses $(50,100$ and $200 \mathrm{mg} / \mathrm{kg})$ but better effect was observed after one hour (late phase). Standard drug, dexamethasone which is a steroid antiinflammatory agent indicated significant reduction in the mean right ear weight of the tested animals (positive control) due to inhibition of phospholipase $A_{2}$ (PL-A2). The results showed that mechanism of action of selected plant extracted samples resembles those of NSAIDs/SAIDs group of the anti-inflammatory drugs. These drugs have anti-inflammatory activities both in central and mainly in peripheral tissue. The significant anti-inflammatory activity of the tested plant is considered to be due to the fact that such plant consists of typical flavonoid type constituents (35). 
Anti-pyretic activity showed dose dependent decrease in the rectal temperature of mice, treated with the tested sample of selected plant. These results showed that the subjected extract of selected plant act both centrally and peripherally (36). Paracetamol reduces the fever by decreasing prostaglandin $\mathrm{E}_{2}$ brain concentration, especially its action on COX-3 in the hypothalamus (37).

Methanol extracts of Tamari aphylly showed significant analgesic effects at higher doses. Acetic acid-induced abdominal constriction assay is a commonly used model. It is sensitive, easy and rapid technique, used to measure peripheral analgesic effect $(38,39)$. This hot plate test is specifically applied to understand the analgesic effect of drugs that act centrally such as tramadol. Anti-nociceptive drugs that act peripherally are found to be inactive on temperature induced hyperalgesia (40). This study revealed the analgesic, antipyretic and anti-inflammatory properties of methanol extract of Tamarix Aphylla (TAME). Our results clearly exhibit that the cited methanol extract has significant analgesic, antipyretic and anti-inflammatory, properties comparable to standard diclofenac sodium/tramadol, paracetamol, indomethacin/dexamethasone

respectively (Table I-V) as supported by in-vivo animal models such as hot plate and acetic acid induced writhing models for anti-nociceptive properties (Table IV-V), brewer yeast induced pyrexia model for anti-pyretic activity (Table III) and carrageenan induced edema and xylene induced ear edema models for anti-inflammatory studies (Table I-II).

\section{CONCLUSION}

It was concluded that the methanol extract of Tamarix aphylla (TAME) depicted dose dependent, statistically significant anti-inflammatory, anti-pyretic and antinociceptive properties. This study 
provides pharmacological base for the medicinal use of Tamarix aphylla in inflammation, pyrexia and algesia. It was noticed during the experiments that the methanol extract of Tamarix Aphylla (TAME) have the prospective to assuage the physical signs of inflammation, algesia/writhes and pyrexia thorough interface of plant constituents with opiodergic receptors (like tramadol) or thorough peripheral (PGs mediated) like aspirin mechanisms. Further studies are needed to isolate effective natural constituents from the extract responsible for cited pharmacological activities.

\section{AUTHORS' NOTE}

The authors declare no conflict of interest. 


\section{REFERENCES}

1. Ali G, Khan A, Samiullah. New drug development process-Today: A review. Pharmacologyonl 2013; 22: 1-10.

2. Butler MS. The role of natural product chemistry in drug discovery. J Natural Products 2004; 67: 2141-53.

3. Patwardhan B. Ethnopharmacology and drug discovery. J Ethnopharmacol 2005; 100: 50-2.

4. Carpenter SR, N. F. Caraco, D. L. Correll, R. W. Howarth, A. N. Sharpley, Smith. VH. Nonpoint pollution of surface waters with phosphorus and nitrogen. Ecological Applica, 1998; 8: 559-68.

5. Felger RS. Flora of the Gran Desierto and Río Colorado of Northwestern Mexico. University of Arizona Press, Tucson, 2000.

6. Hickman JC. The Jepson manual: higher plants of California. University of California Press. Berkeley and Los Angeles, CA, 1993: 1400.

7. Shoureve F, Wiggins. IL. Vegetation and flora of the Sonoran Desert: Vols. I and II. Stanford University Press. Stanford, California., 1964:P. p.1740

8. United States Department of Agriculture NRCS. The PLANTS database, Version 3.1 (http://plants.usda.gov/plants/). National Plant Data Center, Baton Rouge, LA 708744490 USA. 2001.

9. Marwat SK. Salvadora persica, Tamarix aphylla and Zizyphus mauritiana: Thouree Woody Plant Species Mentioned in Holy Quran and Ahadith, and their Ethnobotanical Uses in North Western Part (DI Khan) of Pakistan. Ethnobotanical Leaflets 2008; 2008: 135. 
10. Powell AM. Trees and shourubs of Trans-Pecos Texas including Big Bend and Guadalupe Mountains National Parks. Big Bend Natural History Association, Big Bend National Park, Texas, 1988: 536.

11. Tesky JL. Tamarix ramosissima. In: U.S. Department of Agriculture, Forest Service, Rocky Mountain Research Station, Fire Sciences Laboratory. Fire effects information system. Website: http://www.fs.fed.us/database/feis/plants/tree/tamram/all.html. 1992.

12. Turner RM, Brown. DE. Sonoran desertscrub. In: Brown, D.E. (ed.). Biotic communities of the American Southwest - United States and Mexico. Desert Plants 1982; 4: 181-221.

13. Benson L, Darrow. RA. The trees and shourubs of the Southwestern deserts. The University of Arizona Press, Tucson, Arizona, 1981.

14. Auribie MA. Antioxidant activity of tannin fromTamarix aphylla L. leaves. Basra J Agric.Sci 2011; 24: 33-37.

15. Souliman AM, Barakat HH, El-Mousallamy AM, Marzouk MS, Nawwar MA. Phenolics from the bark of Tamarix aphylla. Phytochem 1991; 30: 3763-6.

16. Marwat SK, Fazal-ur-Rehman, Khan MA, Ahmad M, Zafar M, Ghulam S. Medicinal folk recipes used as traditional phytotherapies in district Dera Ismail Khan, KPK, Pakistan. Pak. J. Bot., 2011; 43: 1453-62.

17. Rao AMa. Medicinal Plants of Cholistan Desert In: Medicinal Plants of Pakistan. P.1. 2001.

18. Abbas B, Al-Qarawi A, Al-Hawas A. The ethnoveterinary knowledge and practice of traditional healers in Qassim Region, Saudi Arabia. J Arid Envir 2002; 50: 367-79.

19. Kamal M, et al. Ethnobotanically important plants of district Bannu, Pakistan. Pak J Plant Sci 2009; 15: 87-93. 
20. Azaizeh H, Salhani N, Sebesvari Z, Shardendu S, Emons H. Phytoremediation of selenium using subsurface-flow constructed wetland. Int. J. Phytorem 2006; 8: 187-98.

21. Shahidullah. Ethnobotanical Studies of district Bannu, N.W.F.P., Pakistan. Ethnobot Leaf 2000; 12: 111-3.

22. H Khan, AA Shad, I Khan, A Aziz, G Ali, SM Hizbullah, I Jan. In vivo and in vitro Pharmacological Evaluation of Gymnosporia royleana. West Indian Med J. 10.7727/wimj.2015.459

23. Muhammad, Khan N, Inamullah, Simjee SU, Gilani AH, Perveen H. Anticonvulsant, analgesic and antipyretic activities of Taxus wallichiana Zucc. J ethnopharmacol., 2008; 116: $490-94$.

24. Asuzu I, Adimorah R. The antiinflammatory activity of extracts from the root of Combretum dolichopetalum. Phytomedicine. 1998; 51:25-8.

25. Cruz MP, Andrade CM, Silva KO, de Souza EP, Yatsuda R, Marques LM, et al. Antinoceptive and Anti-inflammatory Activities of the Ethanolic Extract, Fractions and Flavones Isolated from Mimosa tenuiflora (Willd.) Poir (Leguminosae). PloS one. 2016; 113: $\mathrm{e} 0150839$.

26. Khan I, et al. Anti-inflammatory activities of Sieboldogenin from Smilax china Linn.: experimental and computational studies. J ethnopharmacol, 2009; 121: 175-7.

27. Nunez Guillen, Elena M, da Silva Emim, Artur J, Souccar C, Lapa AJ. Analgesic and Anti-inflammatory Activities of the Aqueous Extract of Plantago major L. Pharm Biol. 1997; 35: 99-104. 
28. Khan M, et al. Antipyretic, analgesic, and anti-inflammatory activities of the seaweed Sargassum fulvellum and Sargassum thunbergii in mice. J Ethnopharmacol 2008; 116: $187-90$.

29. Turner R. Screening Methods in Pharmacology. Acad press., 1965; 1: 105-8.

30. Eddy, Nathan B. Compounds Related to Pethidine-IV. New Genaral Chemical Methods of Increading the Analgesic Activity of Pethidine. J Medicinal Chem 1959; 2: 31-45.

31. Agrawal N. Complications From NSAIDs. Southern Med J 1990; 83: 853-4.

32. Ali G, et al. Comparative evaluation of gastroulcerogenic potential of nitrogen isoforms of salicyl alcohol and aspirin in rats: biochemical and histological study. Arch Pharm Res 2013b: $1-11$.

33. Khan I, et al. Anti-inflammatory activities of Taxusabietane A isolated from Taxus wallichiana Zucc. Fitoterapia, 2011.

34. Lin C, S.C. Lin, C.P. Chang, M.G. Rosenfeld. Pit-1-dependent expression of the receptor for growth hormone releasing factor mediates pituitary cell growth.1992.

35. Okokon JE. Antiinflammatory And Antipyretic Activities Of Panicum Maximum. Afr J Biomed Res, 2011; 14: 125-30.

36. Ferreira SH, Lorenzetti BB, Corrêa FM. Central and peripheral antialgesic action of aspirin-like drugs. Euro J pharmacol 1978; 53: 39-48.

37. Vane JR. Inhibition of prostaglandin synthesis as a mechanism of action for aspirin-like drugs. Nature: New biology, 1971; 232-5.

38. Atta A, Alkofahi A. Anti-nociceptive and anti-inflammatory effects of some Jordanian medicinal plant extracts. J Ethnopharmacol 1998; 60: 117-24. 
39. Gupta M, et al. Anti-inflammatory, analgesic and antipyretic effects of methanol extract from Bauhinia racemosa stem bark in animal models. J Ethnopharmacol 2005; 98: $267-$ 73.

40. Coutaux A, Adam F, Willer J-C, Le Bars D. Hyperalgesia and allodynia: peripheral mechanisms. Joint Bone Spine, 2005; 72: 359-71. 
Table 1: Anti-inflammatory effect of the methanol extract of Tamarix Aphylla (TAME) in Carrageenan-Induced Paw Edema Model

\begin{tabular}{lccccc}
\hline Treatment & Dose & \multicolumn{2}{c}{ 3 hours } & \multicolumn{2}{c}{5 hours } \\
Groups & $(\mathbf{m g} / \mathbf{k g})$ & Difference & \% Inhibitiol & Difference & \% Inhibition \\
\hline Saline & - & $5.92 \pm 0.61$ & - & $6.00 \pm 0.63$ & - \\
TAME & 50 & $5.23 \pm 0.62$ & 17.66 & $4.15 \pm 0.63^{*}$ & 30.84 \\
TAME & 100 & $4.51 \pm 0.58^{*}$ & 23.82 & $3.84 \pm 0.60^{* *}$ & 36.00 \\
TAME & 200 & $3.42 \pm 0.61^{*}$ & 42.23 & $2.89 \pm 0.61 * *$ & 51.84 \\
Indomethacin & 10 & $3.17 \pm 0.60^{* *}$ & 46.46 & $1.92 \pm 0.61^{* *}$ & 68.00 \\
\hline
\end{tabular}

Values are reported as standard error mean \pm (S.E.M.), $n=6,{ }^{*} p<0.05,{ }^{* *} \mathrm{p}<0.01$, compared to saline group, ANOVA followed by Dunnett's test.

Table 2: Anti-inflammatory effect of the methanol extract of Tamarix Aphylla (TAME) in Xylene-Induced Ear Edema Model

\begin{tabular}{lccccc}
\hline $\begin{array}{l}\text { Treatment } \\
\text { Groups }\end{array}$ & Dose & \multicolumn{2}{c}{$\mathbf{1 5}$ min } & \multicolumn{2}{c}{ 60 min } \\
(mg/kg & Difference & \% & Inhibitior & Difference & \% Inhibition \\
\hline Saline & - & $31.78 \pm 2.91$ & - & $32.21 \pm 3.41$ & - \\
TAME & 50 & $19.21 \pm 3.11^{*}$ & 39.56 & $15.09 \pm 2.140^{*}$ & 53.16 \\
TAME & 100 & $14.67 \pm 2.94^{*}$ & 53.84 & $12.51 \pm 3.316^{* *}$ & 61.17 \\
TAME & 200 & $11.91 \pm 2.47^{*}$ & 62.53 & $10.12 \pm 3.316^{* *}$ & 68.59 \\
Dexamethasone & 0.5 & $9.61 \pm 2.77^{*}$ & 69.77 & $8.12 \pm 4.061^{*}$ & 74.80 \\
\hline
\end{tabular}

Values are reported as standard error mean \pm (S.E.M.), $n=6,{ }^{*} p<0.05,{ }^{*} \mathrm{p}<0.01$, compared to saline group. ANOVA followed by Dunnett's test. 
Table 3: Antipyretic activity of the methanol extract of Tamarix Aphylla (TAME) in Brewer Yeast Induced Pyrexia Model

\begin{tabular}{|c|c|c|c|c|c|c|c|c|}
\hline \multirow{3}{*}{$\begin{array}{l}\text { Treatment } \\
\text { Groups }\end{array}$} & \multirow{3}{*}{$\begin{array}{l}\text { Dose } \\
\mathrm{mg} / \mathrm{kg}\end{array}$} & \multicolumn{7}{|c|}{ Rectal temperature $\left({ }^{\circ} \mathrm{C}\right)$} \\
\hline & & \multirow[t]{2}{*}{ Normal } & \multirow[t]{2}{*}{ after $24 \mathrm{~h}$} & \multicolumn{5}{|c|}{ After administration of treatment } \\
\hline & & & & 1h & $2 h$ & $3 \mathbf{h}$ & 4h & $5 h$ \\
\hline Saline & $10 \mathrm{~mL}$ & $36.69 \pm 0.52$ & $39.71 \pm 0.26$ & $38.67 \pm 0.31$ & $38.62 \pm 044$ & $38.61 \pm$ & 38.7 & \\
\hline Paracetamol & 150 & $37.05 \pm 0.32$ & $39.42 \pm 0.32$ & $38.18 * * \pm 0.26$ & $37.78^{* *} \pm 0.36$ & $37.33 * * \pm 0.39$ & $37.41 * * \pm 0.44$ & $37.47 * * \pm 0.47$ \\
\hline \multirow[t]{3}{*}{ TAME } & 100 & $37.07 \pm 0.38$ & $39.53 \pm 0.38$ & $38.61 \pm 0.24$ & $38.44 * \pm 0.41$ & $38.07 * \pm 0.71$ & $38.11 * \pm 0.49$ & $38.09 * \pm 0.37$ \\
\hline & 200 & $37.21 \pm 0.2$ & $39.44 \pm 0.33$ & $38.47 * \pm 0.64$ & $38.09 * \pm 0.43$ & $37.81 * * \pm 0.49$ & $37.84 * * \pm 0.36$ & $37.84 * * \pm 0.47$ \\
\hline & 300 & $37.04 \pm 0.03$ & $39.59 \pm 0.27$ & $38.23 * \pm 0.56$ & $37.92 * * \pm 0.47$ & $37.56^{* *} \pm 0.54$ & $37.69 * * \pm 0.51$ & $37.58 * * \pm 0.38$ \\
\hline
\end{tabular}

Values are reported as mean \pm S.E.M. for group of 6 animals. The data was analyzed by ANOVA followed by Dunnett's test. ${ }^{*} P<0.05,{ }^{* *} P<0.01$ in comparison to control.

Table 4: Antinociceptive activity of the methanol extract of Tamarix Aphylla (TAME) in Acetic Acid Induced Writhing Model

\begin{tabular}{lccc}
\hline $\begin{array}{l}\text { Treatment } \\
\text { Groups }\end{array}$ & Dose (mg/kg, i.p.) & No. of writhing (10min) & \% Analgesia \\
\hline Saline & $10 \mathrm{ml} / \mathrm{kg}$ & $63.38 \pm 2.79$ & - \\
TAME & 100 & $54.71 \pm 2.44$ & 3.68 \\
& 200 & $39.77 \pm 2.26^{*}$ & 50.40 \\
Diclofenac Sodium & 400 & $31.44 \pm 2.11^{* *}$ & 83.96 \\
\hline
\end{tabular}

Values are reported as mean \pm S.E.M. for group of 6 animals. The data was analyzed by ANOVA followed by Dunnett's test.

$* P<0.05,{ }^{*} P<0.01$ in comparison to control. 
Table 5: Antinociceptive activity of the methanol extract of Tamarix Aphylla (TAME) in Hot Plate Analgesia Model

\begin{tabular}{llccccc}
\hline Treatment & Dose $(\mathbf{m g} / \mathbf{k g})$ & \multicolumn{5}{c}{ Latency of nociceptive response (Sec) (mean \pm SEM) } \\
\cline { 3 - 7 } Groups & & 0 & 30 & 60 & 90 & 120 \\
Vehicle & - & $8.22 \pm 0.23$ & $8.48 \pm 0.18$ & $8.61 \pm 0.43$ & $8.68 \pm 0.29$ & $8.74 \pm 0.51$ \\
TAME & 200 & $8.45 \pm 0.31$ & $9.89 \pm 0.52$ & $11.71 \pm 0.67 *$ & $11.94 \pm 0.41^{*}$ & $11.73 \pm 0.53 *$ \\
TAME & 400 & $8.49 \pm 0.58$ & $11.71 \pm 0.64 *$ & $12.89 \pm 0.63^{* *}$ & $13.41 \pm 0.47 * *$ & $12.81 \pm 0.47 * *$ \\
Tramadol & 20 & $8.51 \pm 0.37$ & $12.59 \pm 0.74 * *$ & $15.89 \pm 0.52^{* *}$ & $16.24 \pm 0.23 * *$ & $15.62 \pm 0.23^{* *}$ \\
\hline
\end{tabular}

Values are reported as mean \pm S.E.M. for group of 6 animals. The data was analyzed by ANOVA followed by Dunnett's test.

$* P<0.05, * * P<0.01$ in comparison to control. 



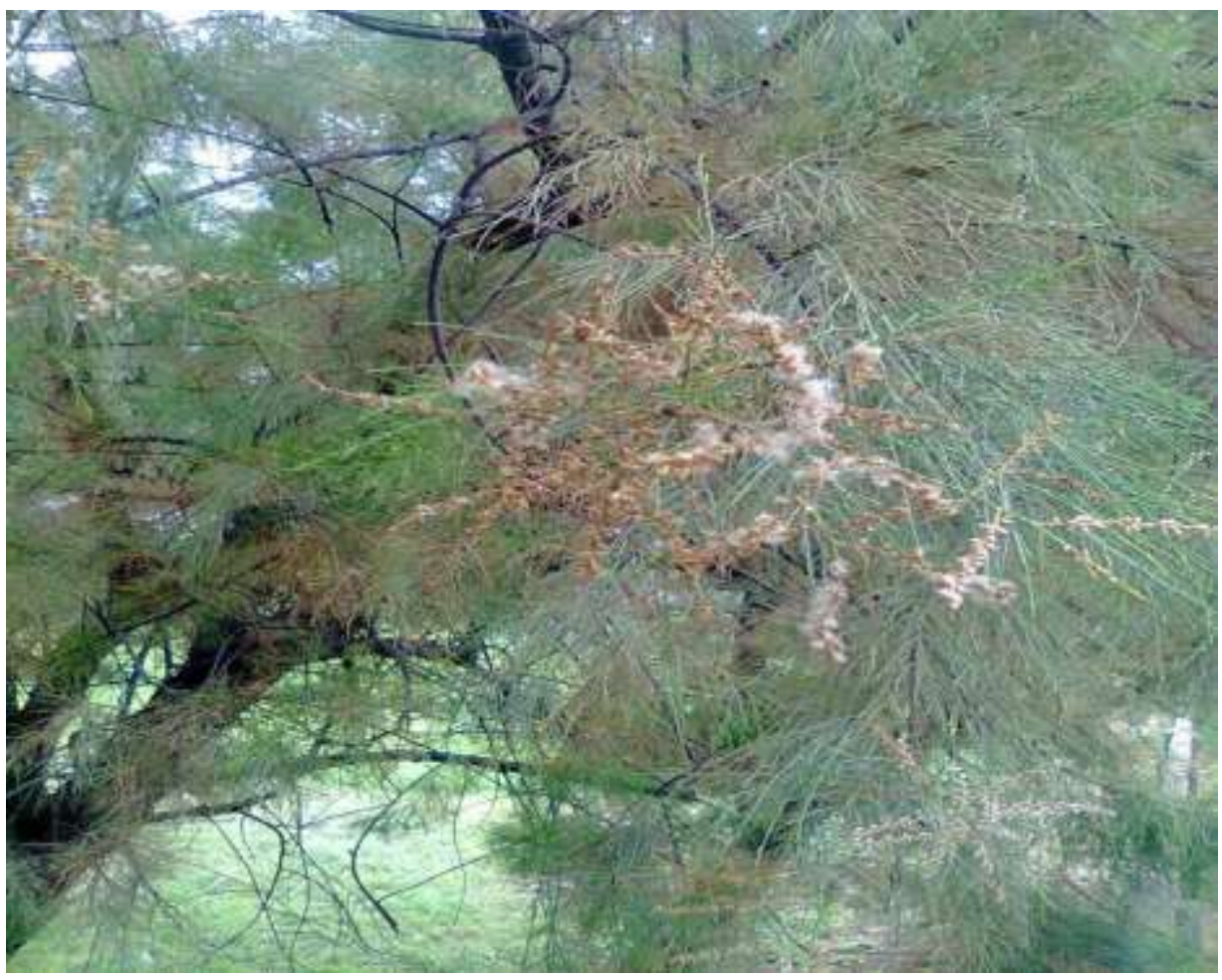

Figure: Photographs of Tamarix aphylla (L) (common name, athel pine) is an evergreen, perennial tree. It belongs to tamaricaceae family. 